\title{
Factors Influencing of Dividend Payout in Indonesia Stock Exchange
}

\author{
Henny Setyo Lestari, Erie Febrian, Sulaeman Rahman Nidar, Rahmat Sudarsono \\ henny_setyo_lestari@trisakti.ac.id
}

Abstract: This research aims to determined the factors that impact dividend policy. The sample used in this research is a manufacturing company that in listed on the Indonesia Stock Exchange (IDX) in the period 20112015. Independent variable in this research is liquidity, investment opportunity, profitability, leverage dan firm size and dependent variable is dividend policy. The amount of the sample of the research amounted to 35 manufacturing companies. The empirical result of this research using the program software Eviews 9.0 by multiples regression analysis. The result of this research indicate that profitability, leverage and firm size has a significant negative effect on dividend policy, while liquidity and investment opportunity have no impact on dividend policy.

Keywords: dividend payout ratio, firm size, investment opportunity, leverage, liquidity dan profitability.

\section{INTRODUCTION}

Generally dividend policy is a problems that is often encountered management and shareholders. In decision dividend policy, management have to make an optimal dividend policy decide the proportion earnings will be given to shareholders and the amount earnings that will be maintained to finance its new investment projects so that to increases future earnings (Mui and Mustapha, 2016). In addition, management also needs to objective in choosing investment that has good prospects, and not otherwise choose investment could even reduce earnings at the expense of earnings that should be distributed to shareholders (Al-Malkawi, 2007). Dividend policy can help to reduce the agency cost.

According to Khan, Naeem, Rizwan and Salman (2016), the high level of liquidity cash reserves larger and more capable of distributed dividend, while companies with low liquidity being a weak in distributed dividend.

Investment opportunity is an opportunity for companies to make new investments to increase return on profit in the future (Mui and Mustapha, 2016). According Al-Kuwari (2009), a firm prioritizes to use internal funding sources to finance investment projects to avoid use of external financing which is relatively more expensive so companies need the proportion pay fewer dividends.

Profitability describe the ability firm in generate profits (Badu, 2013). Earnings obtained are shared to shareholders as a form dividend, this is commitment managements to reward in fulfilling the weatlh maximization shareholders (Yusof and Ismail, 2016). Shareholders expectation companies can create high earnings levels can also distributed a greater amount of dividend.

The use of debt is intended to supporting capital internal as the company gets additional funds other than from shareholders. According Nuhu (2014), companies that uses funding through leverage has an obligation to pay off debts along with interest, so that earnings available to holders are reduce.

Variable last used in this research is firm size. Large companies generally have access more likely to enter the market capital in obtain funding with the relatively lower. So that it can potentially provide higher dividends compared to smaller companies (Al-Malkawi, 2007). The optimal source of capital market funding can fulfilling all funding needed for operational activities. This has lead to the company able to generate earnings to maximum efficiency for shareholders.

www.arjonline.org 
Factors Influencing of Dividend Payout in Indonesia Stock Exchange

Based on the above introduction, with reference to research conducted by Mui and Mustapha (2016), it will be done research with title DETERMINANTS OF DIVIDEND POLICY ON MANUFACTURING COMPANIES LISTED IN INDONESIA STOCK EXCHANGE

\section{RESEARCH METHODS}

The research design used for this research is hypothesis testing with purposed to understand the influence of liquidity, investment opportunity, profitability, leverage dan firm size on dividend policy. Data collected from financial report of manufacturing company that shared dividend has continuously for 5 years and listed in Indonesia Stock Exchange for period of 2011-2015. The analysis toll this research is regression using E-views 9.

\section{Variables and Measurement}

\section{Dependent Variable}

Dependent variable in this study is dividend policy use measured by dividend payout ratio with the formula as follows (Mui and Mustapha, 2016):

$$
\text { Dividend Payout Ratio }=\frac{\text { Dividend Per Share }}{\text { Earning Per Share }}
$$

\section{Independent Variable}

Independent variables in this study liquidity, investment opportunity, profitability, leverage and firm size with the formula as follows (Mui and Mustapha, 2016):

\section{a. Liquidity}

\section{b. Investment opportunity}

$$
\text { Current Ratio }=\frac{\text { Current Assets }}{\text { Current Liabilities }}
$$

\section{c. Profitability}

$$
\text { Market to Book Ratio }=\frac{\text { Market Price Per Share }}{\text { Book Value Per Share }}
$$

\section{d. Leverage}

$$
\text { Return on Equity }=\frac{\text { Net Income }}{\text { Total Equity }}
$$

\section{e. Firm size}

$$
\text { Debt to Equity Ratio }=\frac{\text { Total Debt }}{\text { Total Equity }}
$$

$$
\text { Size }=\text { Natural Logarithm of Total Assets }
$$

\section{Data Analysis Method}

Analysis method used in this study is multiple linear regression. Purpose of this analysis method is to identify relationship of independent variables toward dependent variable. Multiple regression model in this study :

$$
\mathrm{DIV}=\alpha+\beta_{1} \mathrm{LIQ}+\beta_{2} \mathrm{INV}+\beta_{3} \mathrm{ROE}+\beta_{4} \mathrm{LEV}+\beta_{5} \operatorname{SIZE}+\varepsilon_{\mathrm{i}}
$$

where:

$$
\begin{array}{ll}
\text { DIV } & =\text { Dividend payout ratio } \\
\text { LIQ } & =\text { Liquidity } \\
\text { INV } & =\text { Investment opportunity } \\
\text { SIZE } & =\text { Firm size }
\end{array}
$$


Factors Influencing of Dividend Payout in Indonesia Stock Exchange

$\begin{array}{ll}\text { ROE } & =\text { Return on equity } \\ \text { LEV } & =\text { Leverage }\end{array}$

$\mathrm{T}$ test is used to examine the influence of independent variables individually toward dependent variable. Independent variable liquidity, investment opportunity, profitability, leverage and firm size to dependent variable is dividend policy.

\section{RESULTS AND DiscusSiON}

The objects of this study is manufacturing companies listed in Indonesia Stock Exchange for period of 2011 - 2015. Sampling technique used for this study is purposive sampling method, the sampling based on certain criteria, namely manufacturing companies that have gone public and listed in Indonesia Stock Exchange and distribute it dividend continuously for period of 2011 - 2015. Data gathered from 35 companies within a period of 5 years.

Table1. Descriptive Statistics

\begin{tabular}{|l|l|l|l|l|l|l|}
\hline & N & Mean & Median & Maximum & Minimum & Std. Dev \\
\hline DIV & 175 & 0,470023 & 0,431000 & 1,458000 & $-0,588000$ & 0,297423 \\
\hline LIQ & 175 & 2,670303 & 2,124000 & 11,74300 & 0,416000 & 1,848906 \\
\hline INV & 175 & 5,619137 & 3,065000 & 58,48100 & 0,411000 & 9,053497 \\
\hline PROF & 175 & 0,255314 & 0,183000 & 1,435000 & $-0,019000$ & 0,264172 \\
\hline LEV & 175 & 0,720943 & 0,560000 & 3,029000 & 0,108000 & 0,561360 \\
\hline SIZE & 175 & 28,87253 & 28,52300 & 33,13400 & 24,61200 & 1,830905 \\
\hline
\end{tabular}

Source: Eviews 9

Table2. $T$ test result

\begin{tabular}{|l|l|l|l|}
\hline Variable & Coefficient & Probability & Conclusion \\
\hline C & 4,445163 & 0,0029 & - \\
\hline LIQ & $-0,010987$ & 0,4449 & Insignificant \\
\hline INV & 0,008048 & 0,1393 & Insignificant \\
\hline PROF & $-0,617035$ & 0,0018 & Significant \\
\hline LEV & $-0,170057$ & 0,0168 & Significant \\
\hline SIZE & $-0,128527$ & 0,0130 & Significant \\
\hline
\end{tabular}

Source: Output data E-views 9

\section{Liquidity on Dividend Policy}

The result of the coefficient showed liquidity insignificant on dividend policy. The result of this study supported Aqel (2016) found liquidity has no significant on dividend policy. According Gitman and Zutter (2015), this is for current assets are less able to generate profits compared to repairing assets. Fixed assets considered more can give benefits companies because fixed assets can provide value added to products produced company, so liquidity has no effect on dividend policy.

\section{Investment Opportunity on Dividend Policy}

The result of this study reported investment opportunity has no significant effect on dividend policy. It is supported by literature on study Nuhu (2014) that investment opportunity does not effect dividend policy. When investment opportunity of the firm increasing, it will not determine the amount of dividend policy paid by the firm. Khan et al., (2016) showed companies prefer to used earnings obtained through investment into investment opportunities to increase earnings in the future, so did not effect the amount of dividend distributed to shareholders. 


\section{Profitability on Dividend Policy}

The result of the coefficient showed the influence of profitability on dividend policy is -0,617035. Statistical test showed the p-value is $0,0018<0,05$. The result this study supported research by Khan et al., (2016) showed negative effect profitability on dividend policy. Firms with higher profitability generate sufficient amount of earnings and are more able to have retained earnings for reuse the work investment that would improve earnings growth in the future. Based on study Jozwiak (2015) that companies listed of Polish, found a significant negative effect probitability on dividend policy. Companies with high profitability will not fully use earnings for dividend distribution but the earnings is used as a source of investment capital so it will pay a low dividend for shareholders

\section{Leverage on Dividend Policy}

The result of the coefficient showed the influence of leverage on dividend policy is $-0,170057$. Statistical test showed the p-value $0,0168<0,05$. The result of this study reported leverage has a negative effect on dividend policy. The result this study supported research by Patra et al., (2012) that companies of Greece found negative effect of leverage on dividend policy. Firm used external financing through leverage that companies have the obligation to pay the loan along with interest on the loan. So that it reduce the remaining net income used to paying dividends. Research by Al-Kuwari (2009) also found negative effect and significant of leverage on dividend policy.

\section{Firm Size on Dividend Policy}

The result of the coefficient showed the influence of firm size on dividend policy is $-0,128527$. Statistical test showed the p-value $0,0130<0,05$. The result of this study reported firm size has a negative significant effect on dividend policy. According the result by Kouki (2013), large companies generally have a high level of liability because debtholders is more trusted to lend funds to large companies so that company must reduce dividend to paying obligations. While small companies that have little access to the capital market tried to increase demand for their shares to obtain greater funding by paying greater dividends so that if the demand for share by investors increases, companies could issue shares at a better price on the market.

\section{CONCLUSION}

This study aims to determine the effect of liquidity, investment opportunity, profitability, leverage and firm size on dividend policy. This study uses to 35 manufacturing companies listed on the Indonesia Stock Exchange period of 2011-2015. Based on above analysis and discussions, it can be concluded that Liquidity and Investment opportunity has no effect on dividend policy. But Profitability, Leverage and Firm Size have negative effect on dividend policy.

\section{REFERENCES}

1. Afza, T and Mirza, H. H., (2010), "Ownership structure and cash flows as determinants of corporate dividend policy in Pakistan", International Business Research, 3 (3) : 210-221.

2. Aivazian, V and Booth, L., (2003), "Do emerging market firms follow different dividend policies from U.S. firms?”, Journal of Financial Research, 26 (3) : 371-387.

3. Al-Kuwari, D., (2009), "Determinants of the dividend policy in emerging stock exchanges: the case of GCC Countries", Global Economy \& Finance Journal, 2 (2) : 38-63.

4. Al-Malkawi, H. A .N., (2007), "Determinants of corporate dividend policy in Jorand: an application of the tobit model", Journal of Economic and Administrative Sciences, 23 (2) : 44-70.

5. Al-Najjar, B. and Hussainey, K., (2009), "The association between dividend payout and outside directorships", Journal of Applied Accounting Research, 10 (1) : 4-19. 
6. Al-Taleb, G., (2012), "Measurement of impact agency costs level of firms on dividend and leverage policy: an empirical study”, Interdisciplinary Journal of Contemporary Research Business, 3 (10) : 234-243.

7. Alzomaia, T. SF and Al-Khadhiri, A., (2013), "Determination of dividend policy: the evidence from Saudi Arabia”, International Journal of Business and Social Science, 4 (1) : 181-192.

8. Amidu, M. and Abor, J., (2006), "Determinants of dividend payout ratio in Ghana", The Journal of Risk Finance, 7 (2) : 136-145.

9. Aqel, S., (2016), "An empirical investigation of corporate dividend payout policy in an emerging market: Evidence from Palestine securities exchange", Research Journal of Finance and Accounting, 7 (6) : 7-16.

10. Arif, A. and Akbar, F., (2013), "Determinants of dividend policy: a sectoral analysis from Pakistan, International Journal of Business and Behavioral Sciences, 3 (9) : 16-33.

11. Badu, E. A., (2013), "Determinants of dividend payout policy of listed financial institutions in Ghana", Research Journal of Finance and Accounting, 4 (7) : 185-190.

12. Banerjee, S., (2016), "Determinants of dividend policy for selected information technology companies in India: An empirical analysis", Journal of Management, 12 (1) : 152-157.

13. Forti, C. A. B., Peixoto, F. M and Alves, D. L. E., (2015), "Determinant factors of dividend payments in Brazil", Revista Contabilidade \& Finanças, 26 (68) : 167-180.

14. Gill, A., Biger, N and Tibrewala R., (2010), "Determinants of dividend payout ratios: evidence from United States", The Open Business Journal, $3:$ 8-14.

15. Gitman, L. J and Zutter, C. J., (2015), Principles of Managerial Finance, Fourteenth Edition, ISBN-10: 0-13350769-6, ISBN-13: 978-0-13-350769-0, United States: Prentice Hall.

16. Gordon, M. J., (1959), "Dividends, earnings , and stock prices", The Review of Economics and Statistics, 41 (2) : 99-105.

17. Griffin, C. H., (2010), "Liquidity and dividend policy: International evidence", International Business Research, 3 (3) : 3-9.

18. Gul, S., Mughal, S., Bukhari, S. A and Shabir, N., (2012), "The determinants of corporate dividend policy: An investigation of Pakistani banking industry", European Journal of Business and Management, 4(12): 1-5.

19. Hakeem, S. A and Bambale, A. J., (2016), "Mediating effect of liquidity on firm performance and dividend payout of listed manufacturing companies in Nigeria", Journal of Economic, Management, IT, Finance and Marketing, 8 (1) : 15-35.

20. Imran, K., (2011), "Determinants of dividend payout policy: A case of Pakistan engineering sector", The Romanian Economic Journal, 14 (41) : 47-60.

21. Jabbouri, I., (2016), "Determinants of corporate dividend policy in emerging markets: Evidence from MENA Stock Markets", Research in International Business and Finance, 37 : 283-298.

22. Jensen, M. C., (2013), "Agency costs of free cash flow, corporate finance, and takeovers", The American Economic Review, 76 (2) : 323-329.

23. Jensen, M. C and Meckling, W. H., (1976), "Theory of the firm: managerial behavior, agency costs and ownership structure", Journal of Financial Economics, 3 (4) : 305-360.

24. Jozwiak, B. K., (2015), "Determinants of dividend policy: evidence from polish listed companies", Procedia Economics and Finance, 23 : 437-477. 
25. Kaddumi, T. A and Al-Kilani, Q. A., (2015), "Apropos of accounting information indicators as determinants of cash dividend policy decision: A comparative study on Amman Stock Exchange (2001-2013)", International Journal of Economics and Finance, 7 (4) : 135-145.

26. Khan, F. A and Ahmad, N., (2017), "A sectoral analysis of dividend payment behavior", Journal of Financial Studies \& Research, 7 (1): 1-13.

27. Khan, M. N and Shamim, M., (2017), "A sectoral analysis of dividend payment behavior: evidence from Karachi Stock Exchange", SAGE Open, 1-13.

28. Khan, M. N., Naeem, M. U., Rizwan, M and Salman, M., (2016), "Factors affecting the firm dividend policy : An empirical evidence from textile sector of Pakistan", International Journal of Advanced Scientific Research and Management, ISSN 2455-6378, 1 (5) : 144-149.

29. Kieso, D. E., Weygandt, J. J and Warfield T. D., (2014), Intermediate Accounting. Second Edition, ISBN-13 978-1-118-44396-5, John Wiley \& Sons, Inc.

30. Kouki, M. and Guizani, M., (2013), "Ownership structure and dividend policy evidence from the Tehran Stock Market”, European Journal of Scientific Research, ISSN 1450-216X, 25 (1) : 42-53.

31. Labhane, N. B and Mahakud, J., (2016), "Determinants of dividend policy of Indian companies: A panel data analysis", Paradigm, 20 (1) : 1-20.

32. Lintner, J., (1956), "Distribution of incomes of corporations among dividens, retained earnings , and taxes", The American Economic Review, 46 (2) : 97-13.

33. Maldajian, C and Khoury, R. E., (2014), "Determinants of the dividend policy: An empirical study on the Lebanese listed banks", International Journal of Economics and Finance, ISSN 1916-971X, E-ISSN 19169728, 6 (4) : 240-256.

34. Malik, F., Gul, S., Khan, M. T., Rehman, S. U and khan, M., (2013), "Factors influencing ,corporate dividend payout decisions of financial and non-financial firms", Research Journal of Finance and Accounting, 4 (1) : 35-47.

35. Mehta A., (2012), "An empirical analysis of determinants of dividend policy - evidence from the UAE companies", Global Review of Accounting and Finance, 3 (1) : 18-31.

36. Miller, M. H and Modigliani, F., (1961), "Dividend policy, growth, and the valuation of shares", Review Journal of Business, 34 (4) : 411-433.

37. Mui, Y. T and Mustapha, M., (2016), "Determinants of dividend payout ratio: evidence from Malaysian public listed firms", Journal of Applied Environmental and Biological Sciences, ISSN: 2090-4274, 6 (1S) : 48-54.

38. Musa, I. F., (2009), "The dividend policy of firms quoted on the Nigerian Stock Exchange : An empirical analysis", African Journal of Business Management, 3 (10) : 555-566.

39. Musiega, M. G., Alala, O, B., Douglas, M., Christopher, M. $O$ and Robert, E., (2013), “Determinants of dividend payout policy among non-financial firms on Nairobi Securities Exchange, Kenya”, International Journal of Scientific \& Technology Research, 2 (10) : 253-266.

40. Naceur, S. B., Goaied, M and Belanes, A., (2006), "On the determinants and dynamics of dividend policy", International Review of Finance, 6 (1-2) : 1-23.

41. Naser, K., Nuseibeh, R and Rashed, W., (2013), "Managers' perception of dividend policy: Evidence from companies listed on Abu Dhabi Securities Exchange", Issues in Business Management and Economics, 1 (1) : 1-12.

42. Nnadi, M., Wogboroma, N and Kabel, B., (2013), "Determinants of dividend policy: evidence from listed firms in the African Stock Exchanges", Panoeconomicus, 60 (6) : 725-741. 
Factors Influencing of Dividend Payout in Indonesia Stock Exchange

43. Nuhu, E., (2014), "Revisiting the Determinants of Dividend Payout ratios in Ghana”, International Journal of Business and Social Science, 5 (8) : 230-238.

44. Patra, T., Poshakwale, S and Ow-Yong, K., (2012), "Determinants of corporate dividend policy in Greece", Applied Financial Economics, 22 : 1079-1087.

45. Rafique, M., (2012), "factors affecting dividend payout : evidence from listed non-financial firms of Karachi Stock Exchange", Business and Management Dynamics, 1 (11) : 76-92.

46. Rehman, A and Takumi, H., (2012), "Determinants of dividend payout ratio: evidence from Karachi Stock Exchange (KSE)", Journal of Contemporary Issues in Business Research, 1 (1) : 20-27.

47. Ross, S. A., Westerfield, R. A., Jaffe J., Lim, J., Tan, R and Wong, H., (2015), Corporate Finance, Asia Global Edition, ISBN 978-1-259-01183-2, McGraw-Hill Education (Asia).

48. Saeed, R., Riaz, a., Lodhi, R. N., Munir, H. M and Iqbal, A., (2014), "Determinants of dividend payouts in financial sector of Pakistan", 4 (2) : 33-42.

49. Shah, S. Z. I., Ullah, W and Hasnain, B., (2011), "Impact of ownership sturcture on dividend policy of firm", 2010 International Conference on E-Business Management and Economics, 3 : 22-26.

50. Singhania, M and Gupta, A., (2012), "determinants of corporate dividend policy: a tobit model approach", Vision: The Journal of Business Perspective, 16 (3): 153-162.

51. Tabari, N. A. Y and Shirazi, S., (2015), "examining the determinants of dividend policy in listed companies in Tehran Stock Exchange”, Indian Journal of Fundamental and Applied Life Sciences, 5 (S3) : 2375-2382.

52. Thu, N. K., Trien, L. V., Anh, D. T. T and Nhon, H. T., (2013), “Determinants of dividend payments of non-financial listed companies in Ho Chí Minh Stock Exchange", VNU Journal of Economics and Business, 29 (5E) : 16-33.

53. Uwuigbe, U., Jafaru, J and Ajayi, A., (2012), "Dividend policy and firm performance: a study of listed firms in Nigeria", Accounting and Management Information Systems, 11 (3) : 442-454.

54. Yusof, Y and Ismail, S., (2016), "Determinants of dividend policy of public listed companies in Malaysia", Review of International Business and Strategy, 26 (1) : 88-99.

55. Zameer, Hashim, Shahid Rasool, Sajid Iqbal and Umair Arshad. (2013), "Determinants of Dividend Policy: A Case of Banking Sector in Pakistan", Middle-East Journal of Scientific, 18 (3) : 410-424.

56. Zameer, H., Rasool, S., Iqbal, S and Arshad, U., (2013), "Determinants of dividend policy: A case of banking sector in Pakistan”, Middle-East Journal of Scientific, 18 (3) : 410-424.

57. http://www.idx.co.id/

58. http://www.sahamok.com/

Citation: Henny Setyo Lestari, Erie Febrian, Sulaeman Rahman Nidar, Rahmat Sudarsono. "Factors Influencing of Dividend Payout in Indonesia Stock Exchange". American Research Journal of Business and Management. 2019; 5(1): 1-7.

Copyright (c) 2019 Henny Setyo Lestari, Erie Febrian, Sulaeman Rahman Nidar, Rahmat Sudarsono. This is an open access article distributed under the Creative Commons Attribution License, which permits unrestricted use, distribution, and reproduction in any medium, provided the original work is properly cited.

American Research Journal of Business and Management

Page 7 